\title{
Muscovy in the Golden Age in Spain: Chronicles and News Pamphlets ${ }^{1}$ \\ Moscovia en la España del Siglo de Oro: crónicas y relaciones de sucesos
}

\section{Jesús M. Usunáriz}

Universidad de Navarra, GRISO

ESPAÑA

jusunariz@unav.es

[Hipogrifo, (issn: 2328-1308), Volumen extraordinario, 1, 2018, pp. 141-160]

Recibido: 22-05-2017 / Aceptado: 19-06-2017

DOl: http://dx.doi.org/10.13035/H.2018.extra01.10

Abstract. This article analyzes, through various sources, especially «relaciones de sucesos« («pre-periodical printed news») and «chronicles» the Duchy of Muscovy's image in Spain in $16^{\text {th }}$ and $17^{\text {th }}$ centuries. However, if during a good part of both centuries the Duchy was seen as a distant and exotic kingdom, in the second half of the $17^{\text {th }}$ century, thanks to these pamphlets and chronicles that brought news from the Great Turkish War, especially from 1683, Muscovy gained a special interest, unknown until then. This was due to the fact that Russia began to be considered in the development of international diplomatic strategies.

Keywords. Duchy of Muscovy; Spain; Pamphlet News; Chronicles; Great Turkish War; International Affairs; Early Modern History; $16^{\text {th }}$ and $17^{\text {th }}$ Centuries.

Resumen. Este trabajo pretende analizar, a través de diversas fuentes, especialmente, «relaciones de sucesos» y «crónicas» la imagen que se tenía en España del ducado de Moscovia durante los siglos XVI y XVII. No obstante, si durante buena parte de ambos siglos el ducado fue visto como un territorio lejano y exótico, en la segunda mitad del siglo XVII, gracias a las noticias que llegaban de la Gran Guerra Turca, especialmente a partir de 1683, Moscovia cobró un especial interés, desconocido hasta entonces. Esto se debió al hecho de que Rusia comenzaba a ser tenida en cuenta en el desarrollo de las estrategias diplomáticas internacionales.

Palabras clave. Ducado de Moscovia; España; relaciones de sucesos; crónicas; Gran Guerra Turca; relaciones internacionales; siglos XVI y XVII.

1. This work is part of project FFI2014-52007-P, Authority and Power in the Theatre of the Golden Age. Strategies, genres, images in the first globalization, Ministry of Economy and Competitiveness, Government of Spain. Directorate General of Scientific and Technical Research. National Programme for Fostering Excellence in Scientific and Technical Research. 
It is many years - wrote Manuel Villegas in 1736- since my curiosity was aroused by the fact that Spanish ingenuity, so devoted to useful things and undertaking projects, which became a lifelong exercise, was not employed in writing histories of strange countries, in particular of those far away².

The distance between Spain and Russia, the over $4100 \mathrm{~km}$ that lie between Madrid and Moscow, have always been the reason given to explain the lack of news and links between the monarchy in Spain and the ever-growing Grand Duchy of Moscow during the early modern period. Certainly, the distance or the language -and, if you like, the snow, the ice, the thick forests and the barren steppes- may be taken as an explanation that is plausible, but not satisfactory, as the Spanish monarchy, of itself, was in permanent contact with territories all over the globe; and the same obstacles also existed in the $18^{\text {th }}$ century and even in the 19th, and we have knowledge of closer and almost intimate relations during some periods. Well-known are the negotiations launched by Cardinal Alberoni in 1718, when he presented a project for alliance to the Russian ambassador during the Congress of Aland; and the motivation of Peter I to strengthen commercial relations with Spain, particularly after 1721 with the noteworthy presence, beginning in 1723, of consuls and a small colony of Russian merchants in Cadiz, at least until $1727^{3}$. Apart from the aforementioned 1736 book by Villegas on the history of Moscow, we also have the Diario del Viaje a Moscovia which gathers the impressions of the Duke of Liria y Jérica between 1727 and 1730 in the role as ambassador at the court of Muscovy with which he had been entrusted by King Philip $V$ and the project on the union of the Churches ${ }^{4}$-although it was published in the 19th century. In both cases the figure of Czar Peter I was notably applauded ${ }^{5}$. We can also enjoy the works on diplomatic and commercial relationships between the two states between 1733 and 1833 (Schop Soler, 1984) and that on the so-called policy of «opening to the East» by the Count of Floridablanca, particularly after 1774, when, after signing the peace treaty with the Turks, the Russians acceded to free navigation from the Black Sea to the Mediterranean, which the Minister considered as «a very singular and remarkable revolution of the political system $»^{6}$.

However, in this work I would like to look further back and go over the different references and news which were available in Spain regarding the people of Muscovy, and establish a hypothesis, which I shall disclose little by little throughout the following pages, and shall point out in my conclusions. To do so it is indispensable to, a priori, refer to the sources I have used which may be considered «quasiliterary», as, basically, they are what is known as «relaciones de sucesos»? , to-

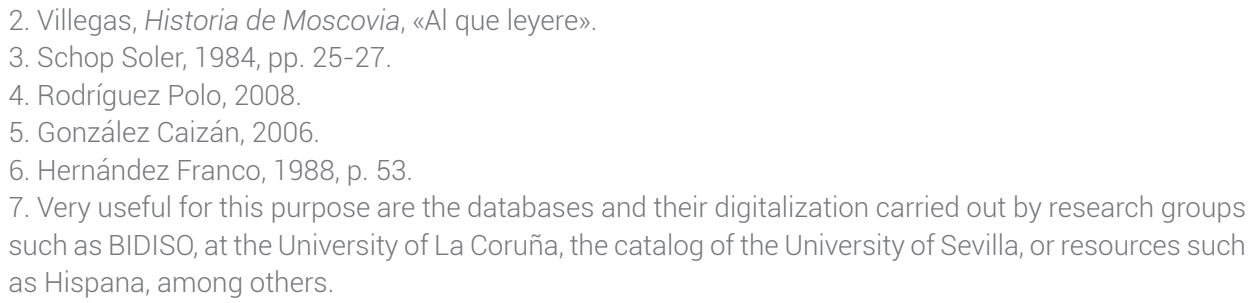


gether with the different types of chronicles which were published during the 16th and 17th centuries in which, from time to time at least, the Grand Duchy of Moscow was mentioned. This source, the pamphlets in particular, originally published isolated military, hagiographic, miraculous and extraordinary news items. Their origin was around 1661, when relatively regular publications were read, such as the Gaceta Nueva by Francisco Fabro Bremundán8. These are documents which, despite their scant historic reliability, «tell about an event that occurred-according to González Cuerva's proper definition - or, on occasion, was invented (but plausible) in order to inform, entertain and move the public -either a reader or listener-»9. Thanks to them we have indications on how the "other» was seen by part of the Spanish press; but in them we can also find apprehension, possibly biased and controlled, in accordance with government directives, regarding international relations in a globalized world. And in our case, that is, the relations of the Spanish monarchy with Muscovy, what we find is that it was towards the end of the 17th century that Spain had access to accurate and precise, almost day-to-day, news of the events and affairs of the faraway, cold and extraordinary Russia. And this demands an explanation.

\section{FARAWAY, EXOTIC, STRANGE, CRUEL MUSCOVY}

The studies and references we can consider regarding Muscovy and its relations with the Spanish monarchy have been limited to a detailed narrative of the outward appearances - but not the true motivations - of embassies sent by the Dukes to the Spanish court; to descriptions of the geography and traditions of the northern duchy; to more or less curious collections of anecdotes; and, what has been most studied, to literary references, particularly in the rich world of Spanish dramaturgy.

Thus, we can take into account works on the subject of several embassies. Thanks to the earlier article by Amada López de Meneses we have the study of what are considered the first Russian embassies to Spain, during the reign of Charles $\mathrm{V}$ as an emperor in $1523,1524,1527,1537$ or $1548^{10}$. Back in the $17^{\text {th }}$ century there were many studies of the embassy that Czar Alexis (1645-1676) sent to the court of the deceased Philip IV; this mission was led by Peter Ivanowitz Potemkin, in order to underline the truce signed with Poland in Andrusovo (1667) and to reach an alliance with Spain against the Turks ${ }^{11}$.

Beginning in the mid-16th century, and probably in imitation of the Italian authors, descriptions of Europe and the world were published without leaving out the Septentrion, the North, and among them, the little-known Duchy of Musco-

8. González Cuerva, 2006, p. 277

9. González Cuerva, 2006, p. 279.

10. López de Meneses, 1946. News from these embassies also in Weiner, 1998

11. Schop Soler, 1984, p. 24. Fernández Izquierdo, 2000. This embassy, which would be repeated by Potemkin in 1680, accompanied by Stepan Polkov, to request military and financial aid due to the attacks by the Turks in Ukrainia, and that of 1688 made up by Jakov Fedorovic Dolgorukov, Jakov Efimovic Myseckov and Kirill Alekseev. See also in Fernández Izquierdo, 2000, pp. 95 and following. 
vy. In 1556, the Granada professor Francisco Tamara devoted several pages to describing the duchy, as one more of his inventory on the customs of the known world ${ }^{12}$. In 1575, in Antonio de Torquemada's Jardín de flores curiosas, in the dialogue between the characters Luis and Antonio, the former asks: «¿No me diréis si este emperador de Rosia que habéis nombrado es tan grande señor como por acá se dice?». And the response is: «No hay que dubdar de que es tan grande que ninguno se puede decir mayor que él entre los príncipes cristianos» ${ }^{13}$. In this work there is no shortage of references, and these are not unique, to the emperor's cruelty, such as the occasion when an Italian ambassador did not remove his hat in the presence of the duke, who «le mandó matar» and when the ambassador explained that the custom in his country was to leave one's hat on, the duke responded «que no quisiese Dios que él quitase tan buen uso, y para confirmarlo mandó que le clavasen el bonete o gorra con dos clavos muy grandes en la cabeza, con la cual luego cayó muerto» ${ }^{14}$. In 1595, Jerónimo Román, in the third part of his Repúblicas del Mundo also collected the duchy's practices and traditions, particularly the religious ones, together with the manner in which the Grand Duke was crowned, or what the Moscovites themselves were like: «son gente cavilosa, llena de mentiras, especialmente con los extranjeros», "y el primero que miente es el duque y señor porque es gran tirano y no guarda ley con nadie»; «otras cosas tienen particulares que parecen más de gente bárbara, que de política» ${ }^{15}$.

In 1603, Giovanni Botero's Relaciones Universales del mundo was published in Spanish, inspired in turn by the reports of the former apostolic nuncio in Moscow, Antonio Possevino, which were published in 1601 with the title De Moscovia ${ }^{16}$. Botero outlined its government (fol. 28v): «Gobierna el gran duque de Moscovia sus estados más despótica y tiranamente que otro ningún o señor o príncipe del mundo [...], porque dispone a su voluntad de las personas, vidas y bienes de sus vasallos». Without omitting allusions to what he called «Riches» and «Strengths» ${ }^{17}$. In 1610 Jaime Rebullosa, based on the Tuscan Relaciones by Giovanni Botero, wrote an ecclesiastical History in which he devoted a brief chapter to the state of religión in Muscovy ${ }^{18}$. The Englishman Sherley, at the service of Phillip III, wrote his Peso de todo el mundo in which he stressed that the Moscovites did not visit any other state «para ver el mundo ni para tratar» «y esta es la causa de la barbariedad que tienen que es llanamente la mayor y más bestial del mundo» (fol. 33r). And he insisted that the country was voluntarily isolated (except from England which it had strong commercial relations), «inimicísimo de la católica» faith, because it was the Jesuits who motivated the Poles to start a war in which «más de un millón de hombres» died -that is to say, the War for Livonia. Moreover, following the trail of other authors, he described its inhabitants, as «gente falsa, sin ley ni palabra, maliciosa, sospechosa

12. Tamara, El libro de las costumbres, fols. $74 \mathrm{r}-75 \mathrm{v}$.

13. Torquemada, Jardín de flores curiosas, p. 530.

14. Torquemada, Jardín de flores curiosas, pp. 532-533.

15. Román, Tercera parte, fols. 13-19r.

16. Smokti, 2003, p. 722

17. Botero, Relaciones universales.

18. Rebullosa, Historia eclesiástica, fols. 112v-115v. 
y tan dada a beber que desde las nueve de la mañana hasta el día siguiente no se puede hacer trato ni negocio con ellos; mentirosos y cruelísimos, pero tan subjetos a sus príncipes que se pueden llamar bestialmente obedientes» (fol. 34v). There are other descriptions published in Spanish, such as that of the Venetian Giovanni Sagredo $(1684)^{19}$, or the story of the travels of the Aragonese preacher Pedro Cubero Sebastián in the 1670s, on how he reached Moscow and spoke at the «corte del emperador de la Rusia», and even managed to say mass in one of the burghs: «No fue poco, señor, porque es la gente más recelosa - otra vez- que tiene todo el mundo», as could be seen in the fact that in over thirty years "no había entrado padre católico». And he made an interesting commentary: «En este burgo, señor, hallé cuantas naciones tiene el mundo, excepto la nación española» ${ }^{20}$.

In a number of chronicles of historical content, some facts considered of special importance are frequently mentioned. In the case of Muscovy, it is unnecessary to mention the references to wars with Poland and Sweden. Herrera y Tordesillas devoted several chapters of the fifth book of the first part of his Historia general del mundo (1601), and of the sixth seventh and eighth book of the second part to the Muscovite wars against the Duchy of Livonia, which they invaded in 1558 - what we call the War for Livonia between 1558 and 1583 between Denmark, Poland, Russia and Sweden for the control of that territory-, where the Muscovites are described as bloodthirsty «bárbaros»; simultaneously he analyzed the origins causes and consequences of that terrible and long-lasting conflict. Moreover, in chapter VIII of book XVI of this first part he even, like other authors, gave a description of the duchy, its religion and government:

Es [el duque] tan temido que nadie se atreve a contradecir su voluntad, la cual tienen sus vasallos por ley, y por ello le llaman «clavero de Dios, ejecutor de los divinos mandamientos». Tiene una corte grandísima con usos muy bárbaros. Guerrea continuamente con los reyes de Suecia y de Polonia y con los tártaros y saca docientos mil caballos en campaña. [...] Viven con pocas leyes ${ }^{21}$.

In 1609, another historian, Luis de Bavia, published the Third part of the Historia pontifical y católica, which contains numerous news items regarding Muscovy: the ambitions of Duke Ivan Vasilevich, that is, Ivan IV, to be elected king of Poland in 1576; the War for Livonia; the Muscovite embassy sent to the Holy See so that Pope Gregory XIII would mediate in the peace negotiations in 1581; the terms of that peace in 1582... And Bavia, like the other authors, could not resist collecting some characteristics of the Muscovites: «aunque en el comer eran templados, en el beber no tanto»; if they fell ill «no llamaban médico, ni hacían otra medicina, porque en Moscovia ni hay médicos, ni boticarios, ni saben qué cosa sea» ${ }^{22}$. «Vive aquella gente en una perpetua inorancia»; del gran respeto y veneración a su príncipe, «les

19. Sagredo, Memorias históricas, pp. 437-438.

20. Cubero, Breve relación, p. 4.

21. Herrera y Tordesillas, Primera parte de la historia general, pp. 749-750

22. Bavia, Tercera parte de la Historia pontifical, p. 178. Negotiations in which the Jesuit Antonio Posevino participated as the nuncio for His Holiness, p. 203 and following. 
viene la sujeción tan grande, que es más esclavitud que vasallaje» (p. 206); and, of course, their cruelty, in this case that of Ivan IV, who assassinated his own son and heir (p. 208). Also, in the fourth part of the Historia pontifical, Bavia devoted two chapters (LXXXVI and LXXXVII) to the surprising exaltation to the throne of False Dimitri in 1605, after the death of Boris Godunov, and the brutal murder of the wife and the son and heir of the latter, Fiodor ${ }^{23}$.

As for news, in the first half of the $17^{\text {th }}$ century there were not many that centered on faraway Muscovy. From 1606 we have the Relación attributed to the Jesuit Mosquera on the case of the False Dimitri ${ }^{24}$. The remainder of those that we have compiled deal with the different conflicts of Muscovy with the Kingdom of Poland in $1634^{25}$, when they do not offer anecdotic revelations on the cruelty of the Muscovites, like the one he lingered over in 1663, with a certain morbid interest, about a Muscovy ambassador in London who, when a merchant complained that one of the diplomat's servants had robbed a piece of silk from him, with no waste of time, invited the merchant to dine and served up on a tray the bloody, recently choppedoff head of the thief ${ }^{26}$.

In Spanish Golden Age literature, references to the Duchy of Muscovy are common. The most outstanding and relevant is, undoubtedly, El gran duque de Moscovia y emperador perseguido (1617) by Lope de Vega, a comedy with historical nuances on the vicissitudes of the imposter czar Dimitri or Pseudo-Demetrius I (1605-1606), a work in which, apart from the exoticism of its setting and the intricacies of its plot, the author reflected on the legitimacy of power ${ }^{27}$. An imaginary Muscovite milieu was created in the Byzantine novel by Enrique Suárez de Mendoza y Figueroa Eustorigio y Clorilene, historia moscóvica (1629). One of the characters in Calderón's La vida es sueño (1635) was the Duke of Muscovy, a pretender to the throne of Poland; Quevedo devoted a chapter with the title «El Gran Duque de Moscovia y los tributos» in his book La Hora de todos y la Fortuna con seso (16351636), which he used to defend a patriarchal vision of the monarchy; and in 1645 Agustín Moreto, Luis de Belmonte and Antonio Martínez wrote the play El príncipe perseguido, el infeliz Juan Basilio, with a plot that was similar to that of $\mathrm{Lope}^{28}$.

In almost all of these, whether they be descriptions, chronicles, relations or dramaturgy, the image presented is the same: a vast, unreasonable territory, im-

23. Bavia, Cuarta parte de la Historia Pontifical.

24. Relación de la señalada y como milagrosa conquista del paterno imperio, conseguida del serenísimo príncipe Iván Demetrio, 1606.

25. Relación verdadera de la insigne victoria que alcanzó el rey de Polonia contra el gran duque de Moscovia y otros confederados suyos, todos enemigos de nuestra santa fe y de las coronas de la casa de Austria, enviada del ejército de su majestad de Polonia, su fecha en 25 de marzo de 1634, Madrid, Francisco de Ocampo, 1634; Las continuas vitorias que ha tenido el serenísimo y potentísimo Vlasdilao, cuarto rey de Polonia, Suecia, etc. y las capitulaciones que admitió para la paz perpetua entre los moscovitas y su reino de Polonia en este año de 1634, Madrid, Viuda de Alonso Martín, 1634.

26. Gaceta nueva de los sucesos políticos, fines de abril de 1663.

27. Brody, 1972; Smokti, 2003. This latter author establishes stimulating connections between the history of False Dimitri and what was beginning to be said about D. Sebastián de Portugal.

28. García Martín, 2013, s. p. Another references in Fernández Izquierdo, 2000, p. 77, n. 5. 
pressive in its dimensions, inhabited by coarse men, «los consideran como bestias», bebedores, caprichosos, exóticos ${ }^{29}$. Although Muscovy was a threat for monarchies such as Sweden or Poland, in Spain, despite the arrival of temporary groups of legates, or the increase in commercial relations, the view of the Grand Duchy was «más literaria que real» ${ }^{30}$. The «bárbaros moscovitas», «gente bruta», «falsos y traidores», «apóstatas y renegados» ${ }^{31}$, «cautos, compuestos, atentos, corteses, pero [con] notable vanidad exterior, amigos de relumbrar en todo» ${ }^{32}$, were a people dominated by a cruel tyrant like Lope de Vega's Basilio, who represented Ivan IV, and was defined as «un nuevo Nerón romano» ${ }^{33}$.

All this, evidently, bears witness to a mutual unfamiliarity, as can be seen in the Spanish clichés regarding the Muscovites, and the scarce contacts between the two monarchies ${ }^{34}$. But not all the illusions were thus, as there was no lack of political reports, memorials and more perceptive stories which offered a more veracious image of the political importance, potentially at least, if not in fact, of Muscovy, particularly in the struggle against the Turks ${ }^{35}$. In 1601, Tommaso Campanella in his La Monarquía de España, maintained the following:

En nuestros días el reino de Polonia es el más poderoso de los reinos septentrionales y si no estuviese desunido por cuestiones religiosas y si su rey fuese designado por sucesión y entre los nativos, y no fuese extranjero, sería un formidable enemigo del Turco, sobre todo si se une con el gran duque de Moscovia ${ }^{36}$.

The above-mentioned traveler Sir Anthony Sherley (1565-1635) in his Peso político de todo el mundo devoted some pages to Muscovy headed with the following reflection:

Aunque parece que el saber de la Moscovia toca poco a esta Monarquía lo hace mucho, por ser tan derramados los estados della que tienen por objeto a los oblicuos o perpendiculares o derechos de todos los potentados y potencias que hay en el mundo ${ }^{37}$.

It is no wonder that, throughout the $17^{\text {th }}$ century, the importance of the Duchy of Muscovy was becoming more marked in the international reality being forged ${ }^{38}$. As

29. López de Meneses, 1946. Sherley, Peso de todo el mundo, fol. 34v.

30. López Cordón, 2005, p. 78.

31. Pellicer, El embajador quimérico, fols. 3v-4v.

32. Fernández Izquierdo, 2000, p. 85.

33. López Cordón, 2005, p. 81.

34. Fernández Izquierdo, 2000, p. 75.

35. According to the historian Lamanskij, Ivan Grozny's victories over the Turks and the Tartars in Kazan and Astrakhan in 1552 and 1556 were partially due to the assistance given by the Spanish monarch after signing a secret alliance with the duke. Schop Soler, 1984, pp. 23-24. We know that Philip II attempted to convince Ivan IV «entrase a formar parte de la Liga antiturca». Schop Soler, 1984, p. 24; Gutiérrez Benito, 1977, p. 56.

36. García Martín, 2013, s.p. The italics are ours.

37. Sherley, Peso político de todo el mundo, fol. 32r. Cit. by Jover, 1950, p. 92.

38. Of interest are the reflections by the Cistercian monk José Arnolfini, who, in his Despertador de los príncipes de Europa, (BNE, ms. 1442), draws a picture of Russia, toward 1663, which was eager to ex- 
Jover or Fernández Izquierdo remind us, the Potemkin embassy to Madrid in 1668 had been instructed, amongst other points, to insist in Spain on the importance «de la unión de todos los reyes príncipes cristianos contras los turcos, que tienen en su poder las tierras cristianas» ${ }^{39}$. And indeed, «tanto para el Gran Ducado Moscovita como para la Corona Española, existía un punto común en política exterior: era éste el afán por frenar el avance del poderío turco» ${ }^{40}$, as Lope de Vega had already warned when he put the following words in the mouth of his Duke of Muscovy character:

$$
\begin{aligned}
& \text { Al emperador quería } \\
& \text { hacer un embajador } \\
& \text { que ofrezca de parte mía } \\
& \text { paz y amistad verdadera } \\
& \text { y gente, como le envía } \\
& \text { Italia, contra la fiera } \\
& \text { buena del turco en Hungría }{ }^{41} \text {. }
\end{aligned}
$$

But until then, and in spite of all these references, Muscovy had not achieved «su plena homologación con otras potencias cristianas» ${ }^{42}$. It would be towards the end of the $17^{\text {th }}$ century, and not in the early 18 th century as has been maintained by Spanish historiography at least, when there would be a complete turnaround.

\section{THE TIME «DE LOS DOS EMPERADORES»: MUSCOVY AS AN ALLY IN THE AUSTRO- OTTOMAN WAR}

In fact, the sporadic news and unusual events, or the references to an exotic and faraway Muscovy, would change in the last two decades of the $17^{\text {th }}$ century ${ }^{43}$. In 1682, Mehmet IV and his Grand Vizier Kara Mustafa decided to resume anti-imperialist policy by supporting the rebellion of Imre Thököly against the Austrian Emperor Leopold. The Turkish intervention in Hungary, which was not unconnected to the manipulations of Louis XIV's France, gave rise to a new war in 1683. Leopold then forged an alliance with John Sobieski's Poland on $20^{\text {th }}$ March of that year ${ }^{44}$. The siege of Vienna begun by the Turkish army in the summer of 1683 ended disastrously for the Ottomans on $12^{\text {th }}$ September, the day of the Battle of Kalenberg,

pand towards the West with its eyes on the Swedish frontier and particularly on the Polish one. López Cordón, 2005, p. 84.

39. Jover, 1950, p. 94. He was to inform the Spaniards regarding the relations that Muscovy already had with France, Denmark, Sweden, the Empire and Persia, its relations with Holland and its enmity with Turkey and the Khan of Crimea.

40. Schop Soler, 1984, p. 23; López Cordón, 2005, p. 79.

41. López Cordón, 2005, p. 82.

42. López Cordón, 2005, p. 78

43. In my opinion, there is no need to wait for the consolidation of the government of Peter 1 from 1696 nor the War of the Spanish Succession, as pointed out by López Cordón, 2005, p. 85, to realize that the presence of Muscovy was a political reality to be taken into account.

44. This alliance and league between Poland and the Emperor is given formal coverage in a relation under the title Manifiesto general. 
after 59 days of siege of the capital. Then was begun the dissolution process of the empire, suffering defeat after defeat, which culminated in February 1699 with the Treaty of Karlowitz and the Ottoman retreat from the whole of the kingdom of Hungary ${ }^{45}$.

Beginning in autumn 1683, the advance of the Christian forces would be continuous due to an alliance diplomatically forged by the Roman curia: in 1684, a Holy League or Sacra Ligua was organized whose initial members were the Holy See, the Emperor, Venice and Poland, and would shortly be joined by the Duchy of Musco$\mathrm{vy}^{46}$. This was a major event, at least for our subject, as, from that moment on, the Duchy would receive uncommon and previously unknown attention in the Iberian Peninsula: over 55 pamphlets of events included Muscovy as one of the unquestionable protagonists of the conflict. A bourgeoning of news ${ }^{47}$ which, coming from Vienna, from Warsaw and other places through Flanders or Italy, from diplomatic couriers and letters sent by Jesuits, was composed in the printing houses of Saragossa, Seville or Madrid and told of the military and political events on the front.

Thus, after the creation of the Sacra Ligua against the Turks, Muscovy attempted to seal alliances by sending ambassadors to Holland, England, Sweden, Denmark, Prussia, France, Spain, Florence, Austria and Venice ${ }^{48}$. But the fundamental coalition was different. On $1^{\text {st }}$ January 1684, the courier from Flanders brought encouraging news to Spain. This news had arrived, in turn, from Warsaw on 2 nd December of the previous year and advised about a Muscovy embassy «from the two emperors» to Constantinople, with such claims and demands that

no se duda ya del rompimiento del moscovita con el Turco, el cual se fomenta con muy grandes y repetidas instancias por los reyes de Polonia y de Suecia, ofreciéndole ventajosos partidos y conveniencias y representándole la ocasión que tiene tan oportuna para restaurar las tierras que le tiene tomadas el Turco ${ }^{49}$.

45. Bérenger, 1992, pp. 307-317.

46. Already when the Austro-Polish Alliance was signed in the spring of 1683 , according to one account, «el embajador de Moscovia muestra deseo de entrar en esta liga contra el Turco y despachó correo a sus príncipes, que son dos (y hermanos) los que gobiernan aquel imperio». Manifiesto general. Furthermore, this treaty explicitly asserted: «y especialmente serán convidados ambos grandes duques de Moscovia». Manifiesto general.

47. This has also been stressed by Díaz Noci, 2008, who underlines the step from mere accounts to periodical gazettes, including serial newssheets based on important events such as, in this case, the war with the Turks. Carabias highlights that the siege of Vienna «desencadenó la mayor producción literaria y noticiosa de este peligro en España: mientras que el triunfo de Lepanto provocó un incremento de la producción impresa circulante en un $260 \%$ en cinco años, el cerco a Viena lo elevó al $1.800 \%$ en el mismo periodo».

48. Hughes, 1998, p. 10.

49. Relación verdadera y noticias generales, 1684. In fact, according to the news in the same account, coming from Venice on 2nd December, there had been a rebellion in Albania, Wallachia and Moldova had been broken up, and «al patriarca de Constantinopla han degollado los turcos por sospecha de inteligencias secretas con los moscovitas». 
From then on, news of the predictable ascription of the Muscovites to the international alliance were frequently repeated: in January 1684, letters forwarded from Vienna in November 1683 informed of the arrival in Lviv (Lwów), Ukraine, of an envoy from Muscovy «con la certeza de lo mucho que habían alegrado a aquella corte las buenas nuevas de Austria y Hungría y de la fervorosa propensión de aquellos príncipes a la motivada alianza». A peace with Poland was being developed, with the mediation of the emperor, so that everyone could «participar de los despojos de los turcos» ${ }^{50}$. The notifications, gazettes and news paid close attention to the agreement negotiations, alternating between excitement and doubt about their success ${ }^{51}$, always with one objective in mind, that is, an attempt to convince the Muscovy czars regarding:

lo que les iba en establecer una amistad firme con la corona de Polonia y en virtud de la mesma unir las fuerzas de ambas potencias en ocasión infalible de aprovecharse a costa del enemigo común, de reinos enteros en lugar de algunas pequeñas provincias o distritos, sobre que era la recíproca contienda ${ }^{52}$.

It was not, however, until $1686^{53}$ that all these complicated negotiations gave the desired result. The signing of the Treaty of Perpetual Peace between the Russians and Poles on $6^{\text {th }}$ May 1686, driven by Prince Vasily Golitsyn, committed Russia to war against Turkey and Crimea, «en nombre de la Cristiandad» ${ }^{54}$, and also guaranteed the Russian dominion of Kiev which until then had been denied. It is true that the first chronicles were quite confusing, as, even in mid-June it was suspected, due to news that had been arriving from Warsaw by means of couriers from Flanders,

que toda esta conferencia ha sido por mera ceremonia de parte de los moscovitas para ganar todo el tiempo del invierno, y que de antemano estaban secretamente convenidos los moscovitas con los turcos en quedar neutrales mediante alguna gran suma de dinero que les dieron los turcos ${ }^{55}$.

But the information published in June ${ }^{56}$ and July 1686 finally confirmed the finalization of the alliance, «cuando Su Divina Majestad inspiró a los Czares disponer se entablasen otra vez las conferencias». In addition, accounts of events and

50. Diario once y doce.

51. Relación histórica del año 1686, 12 de febrero.

52. Relación histórica del año 1686, 12 de febrero.

53. The news told of the advances in these negotiations. Relación histórica del año 1686. 26 March. Later it was pointed out that: «Deteníase todavía en las fronteras de Moscovia la embajada solemne de Polonia aguardando al gran canciller de Lituania, cabo principal de ella, que con maravilla de todos estaba aun en la cercanía de Vilna, en ocasión que los mesmos czares solicitaban acelerar la conclusión de la alianza». 54. Hughes, 1998, p. 10. According to one of the accounts of events published in Spain that year, it was a Jesuit who was behind the signing: «El padre Mauricio Vota, de la Compañía de Jesús, italiano de nación, que algunos años ha fue de parte del señor emperador con carácter de enviado extraordinario a los czares de Moscovia y contribuyó con admirable eficacia a la conclusión de la liga entre Polonia y Moscovia, fundando además a gloria y adelantamiento de la religión católica un colegio para los religiosos de su instituto en Moscou», Octava relación histórica, 1686.

55. Noticias generales de Europa. 15 de junio de 1686; Noticias generales de Europa. 22 de junio de 1686. 56. Noticias generales de Europa. 29 de junio de 1686. 
chronicles gave - quite unusually for its protagonists - detailed terms of the 33 articles of the treaty ${ }^{57}$ which was territorially so onerous for the Poles, and made very positive assessment of an agreement which gave military and strategic impetus to the struggle against the Ottoman ${ }^{58}$ :

Entre las cosas más insignes conseguidas este año para el mayor beneficio de la Cristiandad, ocupa muy debidamente este lugar no solo la paz perpetua, pero la liga y confederación de las dos ínclitas naciones polaca y moscovita contra turcos, habiendo ambas para tan santa resolución superado los envejecidos recíprocos odios y emulaciones, casi inevitables entre dos grandes potencias confinantes, fáciles a encenderse en guerras ${ }^{59}$.

Without delay, the Muscovy military machine was unleashed, as reported in Spain in the month of August ${ }^{60}$. The consequences were soon seen. Firstly, the Russo-Polish alliance prevented the Tartars from sending troops to assist the Sultan, as they were concerned by the presence of the armies of Muscovy and Poland ${ }^{61}$. But the most important point which must not be forgotten is that «por primera vez en la historia de Rusia, Moscovia formaba parte de una coalición de potencias europeas que luchaban contra un enemigo común»62. From that moment on, and in the following months, most of these serialized publications on the holy war against the Turks gave news on the advances, and setbacks, of the Muscovy operations in Crimea against the Tartars in the campaigns of $1687^{63}$ y $1689^{64}$. Simultaneously, Muscovy, by means of new embassies, was attempting to strengthen the European

57. Relación histórica del año 1686. 9 de julio. See the text of the Treaty, which produced great rejoicing, in the Appendix. As is written in one account, the resident imperial Baron Zerowski roads the news of the peace settlement to the Emperor. According to the legate, he «había dejado la corte de Polonia llena de gozo y en vísperas de hacer grandes demonstraciones de alegría por un suceso de tan relevantes consecuencias a aquella corona y a toda la cristiandad». Relación histórica del año 1686. 16 de julio. The full negotiations were also gathered in detail in Fabro, Floro histórico, pp. 54-71.

58. Relación histórica del año 1686. 16th June.

59. Fabro, Floro histórico, p. 54.

60. Relación histórica del año 1686. 13 de agosto. En las Noticias extraordinarias del Norte. 9 de agosto; Noticias generales de Europa. 7 de diciembre de 1686.

61. Octava relación histórica, 1686

62. Massie, 1986, p. 78.

63. Noticias extraordinarias del Norte. 3 de agosto. 1686; Noticias generales de Europa, 11 de enero; Relación histórica del año 1687, 14 de enero; Noticias generales de Europa, 15 de febrero; Relación verdadera de las vitorias que han tenido las armas de Moscovia, 1687; Relación histórica del año 1687, 18 de febrero; Relación histórica del año 1687, 18 de marzo; Relación histórica del año 1687, 8 de abril; Relación histórica del año 1687, 22 de abril; Relación histórica del año 1687, 3 de junio; Noticias principales y verdaderas, 28 de junio a 22 de julio; Relación histórica del año 1687, 1 de julio; Relación histórica del año 1687, 26 de agosto; Relación histórica del año 1687, 21 de octubre; Relación histórica del año 1687, 29 de octubre; Relación verdadera de las vitorias que han tenido las armas de Moscovia, 1687; Relación histórica del año 1687, 12 de agosto; Relación histórica del año 1687, 7 de octubre; Relación histórica del año 1687, 18 de octubre; Relación histórica del año 1687, 4 de noviembre y 14 de noviembre de 1687. 64. Noticias extraordinarias de Turquía, Moscovia y España, 1689; Noticias generales de las cosas de Europa, 19 de julio de 1689; Noticias ordinarias del Norte, 1 de septiembre de 1689; Noticias ordinarias del Norte, 14 de septiembre de 1689; Noticias generales de Europa, 17 de septiembre de 1689. 
anti-Turk alliance ${ }^{65}$ with its closest partners, the Poles ${ }^{66}$, in order to freeze the conversations which had been begun that year by Poland and Austria with the Sublime Porte so that France could use them to attempt to break up the coalition, particularly with the Austrian Empire ${ }^{67}$.

Nevertheless, despite the triumphalist tone of some accounts, they could not hide the fact that the campaigns fueled by Vasily Golitsyn resulted in numerous losses, thereby creating a state of unrest which was used by Czar Peter to conspire against the Regent Sophia. Finally she was overthrown in September of that year ${ }^{68}$.

In fact, while the news on the war arrived regularly, there was no lack of reports on the interior situation in the Duchy which, in 1689, was critical and could affect future campaigns and the coalition itself.

Reports were sent from Lviv on $31^{\text {st }}$ October 1689, «con noticias bien extravagantes» referring to the 8th and 17th of the same month: the conspiracy against Czar Ivan, «el menor de los dos zares hermanos», led by Prince Golitsyn, who was at once banished «a los desiertos de Siberia con su esposa e hijos», and by Princess Sophia, who was immediately forced to withdraw to a convent. However, the chronicles reported, confusedly, the involvement and even an alliance between Czar Peter and Sophia, although, in the end, he chose to dispense with «toda la autoridad que le competía en el gobierno» ${ }^{69}$.

If the chronicles noted these grave or «extravagant» incidents in the court of Moscow $^{70}$, no longer was it to reflect the cruelty and barbarity of its dignitaries, but rather the consequences that might arise if the military impulse of the Duchy of Crimea were curbed, as this duchy was essential to «divertir los tártaros de cualquiera operación que puedan emprender contra nosotros o contra nuestros aliados $»^{71}$. And also because, at least for the pamphlets, behind this unrest

65. Fernández Izquierdo, 2000, p. 100 and following.

66. Noticias extraordinarias de Turquía, Moscovia y España, 1689; Gaceta general de Europa, 11 de junio de 1689. The same text appears in Noticias generales de Europa, 11 de junio de 1689.

67. Noticias generales de Europa, 5 de marzo de 1689.

68. Hughes, 1998, pp. 10-11.

69. Noticias ordinarias del Norte. 3 de enero de 1690. On $10^{\text {th }}$ January in news from Moscow dated 23rd October 1689, the conspiracies against Czar Ivan were confirmed, «quedando solo en el trono este príncipe», after the cession of authority by his brother Peter. The news had changed, and Golitsyn was not dead but travelling to exile, «cargado de cadenas». And it adds: «Continuábase en inquirir sus cómplices y cada día se hallaban algunos, aún eclesiásticos, nobles y mujeres, que todos pagaban la pena de su delito con el último suplicio». Noticias ordinarias del Levante y del Norte. 10 de enero de 1690. News also published in Noticias principales y verdaderas, 22 de noviembre a 6 de diciembre de 1689.

70. Noticias ordinarias del norte, 24 de enero de 1690; Noticias principales y verdaderas. 20 de diciembre de 1689-3 de enero de 1690; Noticias generales de Europa, 24 de diciembre de 1689; Noticias ordinarias del Norte e Italia, 7 de marzo de 1690; Noticias ordinarias del Norte e Italia, 21 de marzo de 1690; Noticias ordinarias del Norte, Italia y España. 21 de noviembre de 1690.

71. Noticias ordinarias del Norte e Italia, 7 de febrero 1690; Noticias principales y verdaderas. 3-17 de enero de 1690. 
undoubtedly lay French diplomatic manoeuvrers, «los olores de las lises» were attempting to «embarazar los sentidos» of the czar².

However, everything settled down: Ivan had not, by any means, become the leader of the Empire. Peter had won over and would, from then on, head the government and continue with his alliance with the Turks:

A esto mesmo pertenece la nueva muy reciente de que el czar Pedro de Moscovia (cuya autoridad es la que actualmente prevalece en aquellos dilatados dominios) tiene apercibidos hasta quinientos mil hombres para invadir la Crimea y otros estados del Turco ${ }^{73}$.

\section{IN CONCLUSION}

Spain had little knowledge of Muscovy during most of the $16^{\text {th }}$ and $17^{\text {th }}$ centuries. While it is true that the distance may be an excuse and an explanation, I do not, in fact, believe it to be reason enough. If Muscovy was unimportant for the Spanish monarchy it is mostly for exclusively geopolitical reasons. Until well into the $17^{\text {th }}$ century, the Grand Duchy was not a player of significance for Spanish interests in Europe, in the North Sea or the Mediterranean, for which reason Spain played a role as mediator in the on-going conflicts between the northern nations and was, almost always, predisposed to support the Catholic Republic of Poland. However, when, in the 1680s, the Habsburgs began to stand out due to the continuing decline of the Ottomans in Central and Eastern Europe, the participation of Muscovy in an international coalition, probably for the first time, meant that the magnificent Russian empire had to be considered as a key player in the development of international diplomatic strategies.

It was then that these serialized publications in Spain began to set aside the clichés about that faraway Muscovy, forested, brutal, cruel and barbarian, and began to contemplate the fact that it might finally be an effective ally against a common enemy, due to the possibility of bringing together incredible experienced military contingents, to the development of its artillery and a territorial expansion ever closer to the European reality. Nevertheless, it is curious - or perhaps not- that this Spanish perception of the Muscovites through the news boom in the 80s occurred precisely when the Spanish forces had little to do with the Eastern front and were more concerned by the impetus and pressure of the French in the West, at the expense, specifically, of the Spanish possessions. Moreover, over and above the possible popularity of the accounts of events among a public that was avid to read and hear international news ${ }^{74}$, the Spanish monarchy considered the success of the Austrian House of Habsburg in the East to be a compensation for the continuous humiliations which the Spanish and Central European Habsburgs had been suffering at the hands of the French since 1648 and particularly as one more argument

72. Noticias generales de Europa, 10 de junio de 1690.

73. Noticias ordinarias del Norte, Italia y España. 21 de noviembre de 1690.

74. Carabias, 2010 
against the French enemy during the Nine Years' War. And for this reason the victories of an international Christian coalition against the infidel, in which Muscovy was one of the main players, were useful, if not to hide, at least to minimize a growing sense of defeat.

\section{BIBLIOGRAPHY}

Álvarez de Toledo, Alonso, «Embajador del zar en la corte de Carlos Il», Historia 16, 16, 1977, pp. 60-64.

Bavia, Luis de, Cuarta parte de la Historia Pontifical y Católica, Madrid, Melchor Sánchez, 1652.

Bavia, Luis de, Tercera parte de la Historia Pontifical y Católica, Barcelona, Sebastián de Cormellas, 1609.

Bérenger, Jean, El imperio de los Habsburgo 1273-1918, Barcelona, Crítica, 1992.

Botero, Juan, Relaciones universales del mundo [...] Primera y segunda parte, Valladolid, Herederos de Diego Fernández de Córdoba, 1603.

Brody, Ervin C., The Demetrius Legend and Its Literary Treatment in the Age of the Baroque, Rutherford, Fairleigh Dickinson University Press, 1972.

Carabias Torres, Ana M., «La producción editorial sobre el Imperio otomano y los turcos en España (1470-1850). Una investigación in fieri», Tiempos Modernos. Revista Electrónica de Historia Moderna, 7, 20, 2010, pp. 1-35.

Cubero Sebastián, Pedro, Breve relación de la peregrinación que ha hecho de la mayor parte del mundo don Pedro Cubero Sebastián, Madrid, Juan García Infanzón, 1680.

Diario once y doce. Nuevas singulares del Norte y de Europa y otras partes. Publicadas el martes 17 de enero y martes 18 de enero de 1684, Sevilla, Tomás López de Haro, 1684.

Díaz Noci, Javier, «El Mediterráneo en guerra. Relaciones y gacetas españolas sobre la guerra contra los turcos en la década de 1680», in España y el mundo mediterráneo a través de las Relaciones de Sucesos: Actas del IV Coloquio Internacional sobre Relaciones de Sucesos, coord. Pierre Civil, Françoise Cremoux and Jacobo S. Sanz Hermida, Salamanca, Universidad de Salamanca, 2008, pp. 131-140.

Fernández Izquierdo, Francisco, «Las embajadas rusas a la corte de Carlos II», Studia Histórica. Historia Moderna, 22, 2000, pp. 75-107.

Gaceta general de Europa venida a Zaragoza por el correo de Flandes, sábado a 17 de junio de 1689, Sevilla, Juan Antonio Tarazona, 1689. 
Gaceta nueva de los sucesos políticos y militares de la mayor parte de América, Asia y Europa hasta los fines de abril de mil y seiscientos y sesenta y tres, Sevilla, Juan Gómez de Blas, 1663.

García Martín, Pedro, De Moscovia a Rusia, Pamplona, leer-e, 2013.

González Caizán, Cristina, «La Rusia de Pedro I y la Francia de Luis XIV en el pensamiento político español de mediados del siglo XVIII», Cuadernos de Estudios del siglo XVIII, 16, 2006, pp. 113-130.

González Cuerva, Rubén, «"El prodigioso príncipe transilvano": la larga guerra contra los turcos (1593-1606) a través de las relaciones de sucesos», Studia Histórica. Historia Moderna, 28, 2006, pp. 277-299.

Gutiérrez Benito, Felipe, «Cinco siglos de relaciones España-Rusia», Historia 16, 16, 1977, pp. 55-59.

Hernández Franco, Juan, «Una alternativa al organigrama de las relaciones exteriores de España durante el siglo XVIII: el acercamiento a Rusia», in Homenatge al doctor Sebastià Garcia Martinez, València, Generalitat Valenciana/Universitat de València, 1988, vol. III, pp. 51-60.

Herrera, Antonio de, Primera parte de la historia general del mundo, de XVII años del tiempo del señor rey don Felipe II el Prudente, desde el año MDLIIII hasta el de MDLXX, Valladolid, Juan Godínez de Millis, 1606.

Herrera, Antonio, Segunda parte de la historia general del mundo de XI años de tiempo del señor rey don Felipe II el Prudente, desde el año MDLXXV hasta el de MDLXXXV, Madrid, Pedro Madrigal, 1601.

Hughes, Lindsey, Russia in the Age of Peter de Great, New Haven/London, Yale University Press, 1998.

Jover Zamora, José María, «El sentimiento de Europa en la España del XVII. Valoración nacional y valoración política de la pluralidad europea», Saitabi, 8, 35-38, 1950, pp. 72-99.

López Cordón, María Victoria, «De Moscovia a Rusia: caracteres nacionales y límites europeos en el imaginario español de los siglos XVII y XVIII», Saitabi, 55, 2005, pp. 77-98.

López de Meneses, Amada, «Las primeras embajadas rusas en España (1523, 1525 y 1527)», Bulletin Hispanique, 48, 3, 1946, pp. 210-226.

Manifiesto general que hace su majestad cesárea y el rey de Polonia y otros diferentes príncipes en que declaran las razones que tienen para romper guerra contra el gran turco, en que se concluyó entre el señor emperador y el señor rey de Polonia la alianza y liga ofensiva y defensiva contra el Turco. Refiérense los capítulos della y el juramento que hacen ambas majestades en manos de su santidad por medio de los eminentísimos cardenales Pío y Barberino, SeviIla, Juan Francisco de Blas, 1683. 
Massie, Robert K., Pedro el Grande. Su vida y su mundo, Madrid, Alianza, 1986.

Noticias extraordinarias de Levante y del Norte, publicadas martes a 10 de enero 1690, Madrid, Sebastián de Armendáriz, 1690.

Noticias extraordinarias de Turquía, Moscovia y España, publicadas martes a 30 de agosto, 1689, Madrid, Imprenta de Antonio Román, 1689.

Noticias extraordinarias del Norte de 3 de agosto, de Viena de 14 de julio de 1686, s.l., s.n., 1686.

Noticias extraordinarias del Norte y África, publicadas martes a 3 de enero 1690, Madrid, Sebastián de Armendáriz, 1690.

Noticias generales de Europa venidas a Zaragoza por el correo de Flandes el sábado a 22 de junio de 1686, Zaragoza, s.n., 1686.

Noticias generales de Europa venidas a Zaragoza por el correo de Flandes el sábado a 29 de junio de 1686, Zaragoza, s.n., 1686.

Noticias generales de Europa venidas a Zaragoza por el correo de Flandes el sábado a 7 de deciembre de 1686, Zaragoza, s.n., 1686.

Noticias generales de Europa venidas a Zaragoza por el correo de Flandes, sábado a 10 de junio de 1690, Zaragoza, s.n., 1690.

Noticias generales de Europa venidas a Zaragoza por el correo de Italia, martes a primero por el de Flandes, sábado a 5 de marzo de 1689, Zaragoza, s. n., 1689.

Noticias generales de Europa venidas a Zaragoza por el correo de Italia, martes a primero por el de Flandes, sábado a 11 de junio de 1689, Zaragoza, s. n., 1689.

Noticias generales de Europa, venidas a Zaragoza por el correo de Flandes el sábado a 15 de junio de 1686, Zaragoza, s.n., 1686.

Noticias generales de Europa, venidas a Zaragoza por el correo de Flandes, sábado a 17 de septiembre 1689, Zaragoza, Heredero de Diego Dormer, 1689.

Noticias generales de Europa, venidas a Zaragoza por el correo de Italia, jueves a 22 y por el de Flandes a 24 de deciembre, 1689, Zaragoza, Heredero de Diego Dormer, 1689.

Noticias generales de Europa, venidas à Zaragoza por el Correo de Flandes el Sábado à 11 de Enero de 1687, Zaragoza, s.n., 1687.

Noticias generales de Europa, venidas à Zaragoza por el Correo de Flandes el Sábado à 15 de Febrero de 1687, Zaragoza, s.n], 1687.

Noticias generales de las cosas de Europa, según vinieron con los últimos correos y se publican martes 19 de julio de 1689, Sevilla, Tomás López de Haro, 1689.

Noticias ordinarias del Norte e Italia, publicadas martes a 21 de marzo 1690, Madrid, Sebastián de Armendáriz, 1690. 
Noticias ordinarias del Norte e Italia, publicadas martes a 7 de febrero 1690, Madrid, Sebastián de Armendáriz, 1690.

Noticias ordinarias del Norte e Italia, publicadas martes a 7 de marzo 1690, Madrid, Sebastián de Armendáriz, 1690.

Noticias ordinarias del norte, Grecia, Italia y África, publicadas martes a 24 de enero 1690, Madrid, Sebastián Armendáriz [Antonio Román], 1690.

Noticias ordinarias del Norte, Italia y España, publicadas jueves 1 de septiembre de 1689, Sevilla, Tomás López de Haro, 1689.

Noticias ordinarias del Norte, Italia y España, publicadas miércoles 14 de septiembre de 1689, Sevilla, Tomás López de Haro, 1689.

Noticias principales y verdaderas. Desde 28 de junio, hasta 22 de julio de 1687. Publicada sábado 23 de agosto, Sevilla, Cristóbal López, 1687.

Noticias principales y verdaderas. Desde 3 hasta 17 de enero 1690, Bruselas, Pedro de Cleyn, 1690.

Noticias principales y verdaderas. Desde el 20 de deciembre 1689 hasta el 3 de enero 1690, Bruselas, Pedro de Cleyn, 1690.

Noticias principales y verdaderas. Desde el 22 de noviembre hasta 6 de diciembre, San Sebastián, Bernardo de Huarte y Francisca de Aculodi, 1689.

Octava relación histórica y segundo diario del año 1686 tocante al estado, sucesos y progresos de la Liga sagrada contra turcos, formada de las últimas cartas de Italia y el Norte. Publicada jueves 7 de noviembre, Sevilla, Tomás López de Haro, 1686.

Pellicer, José, El embajador quimérico o examinador de los artes políticos del cardenal duque de Richilieu, Valencia, José Esparza, 1638.

Rebullosa, fray Jaime, Historia eclesiástica y estado presente de la religión en todos los reinos de Europa, Asia y África, sacada de las relaciones toscanas de Juan Botero, Barcelona, Hierónimo Margarit, 1610.

Relación de la señalada y como milagrosa conquista del paterno imperio, conseguida del serenísimo príncipe Iván Demetrio, gran duque de Moscovia en el año de 1605, juntamente con su coronación y con lo que ha hecho después que fue coronado, dende el último mes de julio hasta agora, recogido todo de varios y veraderos avisos venidos de aquellas partes en diversas veces. Traducido de la lengua italiana en nuestro vulgar castellano, Lisboa, Antonio Álvarez, 1606.

Relación histórica del año 1686 tocante al estado, sucesos y progresos de la liga sagrada contra los turcos, formada de las últimas cartas de el norte e Italia, publicada el martes 13 de agosto, Madrid, Sebastián de Armendáriz, Antonio Román, 1686. 
Relación histórica del año 1686 tocante al estado, sucesos y progresos de la liga sagrada contra los turcos, formada de las últimas cartas de el norte e Italia, publicada el martes 12 de febrero, Madrid, Sebastián de Armendáriz, Antonio Román, 1686.

Relación histórica del año 1686 tocante al estado, sucesos y progresos de la liga sagrada contra los turcos, formada de las últimas cartas de Italia y el Norte, publicada el martes 12 de marzo, Madrid, Sebastián de Armendáriz, 1686.

Relación histórica del año 1686 tocante al estado, sucesos y progresos de la liga sagrada contra los turcos, formada de las últimas cartas de Italia y el Norte, publicada el martes 26 de marzo, Madrid, Sebastián de Armendáriz, 1686.

Relación histórica del año 1686 tocante al estado, sucesos y progresos de la liga sagrada contra los turcos, formada de las últimas cartas de Italia y el Norte, publicada el martes 16 de julio, Madrid, Sebastián de Armendáriz, 1686.

Relación histórica del año 1687. Tocante al estado, sucesos, y progresos de la Liga sagrada contra Turcos. Formada de las ultimas cartas de Italia, y el Norte. Publicada el Martes 14. de Enero, Madrid, Sebastián de Armendáriz, en la imprenta de Antonio Román, 1687.

Relación histórica Del año 1687. Tocante al estado, sucesos, y progresos de la Liga Sagrada contra turcos, formada de las ultimas cartas de Italia, y el Norte. Publicada el Martes 18 de Febrero, Madrid,, Sebastián de Armendáriz, en la imprenta de Antonio Román, 1687.

Relación histórica del año 1687. Tocante al estado, sucesos, y progresos de la Liga Sagrada contra turcos, formada de las ultimas cartas de Italia, y el Norte. Publicada el martes 18 de Marzo, Madrid, Sebastián de Armendáriz, 1687.

Relación histórica del año 1687. Tocante al estado, sucesos, y progresos de la Liga Sagrada contra turcos. Formada de las ultimas cartas de Italia, y el Norte. Publicada el Martes 8 de Abril, Madrid," Sebastián de Armendáriz, 1687.

Relación histórica Del año 1687. Tocante al estado, sucesos, y progresos de la Liga Sagrada contra Turcos. Formada de las ultimas cartas de Italia, y el Norte. Publicada el Martes 22 de Abril, Madrid, Sebastián de Armendáriz, 1687.

Relación histórica del año de 1687 tocante al estado, sucesos, y progresos de la liga sagrada contra turcos. Formada de las últimas cartas de Italia, y el Norte. Publicada miércoles 29 de octubre, Sevilla, Cristóbal López, 1687.

Relación histórica del año de 1687. Tocante al estado, sucesos, y progresos de la Liga sagrada contra Turcos. Formada de las últimas cartas de Italia, y el Norte. Publicada en Sevilla, Sábado 18 de Octubre de 1687, Sevilla, Cristóbal López, 1687.

Relación histórica del año de 1687. Tocante al estado, sucesos, y Progresos de la Liga Sagrada contra Turcos. Formada de las últimas cartas de Italia, y el Norte. Publicada el Viernes 14 de Noviembre, Sevilla, Cristóbal López, 1687. 
Relación histórica del año M.DC.LXXXVII. Tocante Al estado, sucesos, y progresos de la Liga sagrada contra turcos, formada de las ultimas Cartas de Italia, y el Norte. Publicada el Martes 3. de Junio, Madrid, Sebastián de Armendáriz, en la imprenta de Antonio Román, 1687.

Relación histórica del Año M.DC.LXXXVII. Tocante Al estado, sucesos y progresos de la Liga sagrada contra Turcos. Formada de las ultimas Cartas de Italia, y el Norte. Publicada el Martes 1. de Julio, Madrid, Sebastián de Armendáriz, 1687.

Relación histórica del año M.DC.LXXXVII. Tocante Al estado, sucesos, y progresos de la Liga sagrada contra turcos, formada de las ultimas Cartas de Italia, y el Norte. Publicada el Martes 12 de Agosto, Madrid, Sebastián de Armendáriz, en la imprenta de Antonio Román, 1687.

Relación histórica del año M.DC.LXXXVII. Tocante al estado, sucesos, y progresos de la Liga sagrada contra turcos, formada de las ultimas Cartas de Italia, y el Norte. Publicada el Martes 26. de Agosto, Madrid, Sebastián de Armendáriz, en la imprenta de Antonio Román, 1687.

Relación histórica del año M.DC.LXXXVII. Tocante Al estado, sucesos, y progresos de la Liga sagrada contra turcos, formada de las ultimas Cartas de Italia, y el Norte. Publicada el Martes 7 de Octubre, Madrid, Sebastián de Armendáriz, en la imprenta de Antonio Román, 1687.

Relación histórica del año M.DC.LXXXVII. Tocante al estado, sucesos y progresos de la Liga sagrada contra turcos, formada de las ultimas Cartas de Italia, y el Norte. Publicada el Martes 21 de Octubre, [Madrid], Sebastián de Armendáriz, En la Imprenta de Antonio Román, 1687.

Relación histórica del año M.DC.LXXXVII. Tocante al estado, sucesos, y progresos de la Liga sagrada contra turcos, formada de las ultimas Cartas de Italia, y el Norte. Publicada el Martes 4. de Noviembre, Madrid, Sebastián de Armendáriz, 1687.

Relación verdadera de las vitorias que han tenido las armas de Moscovia contra turcos. Y vitoria obtenida por la armada de Francia contra los moros de Argel. Y otra vitoria que tuvieron las galeras del señor duque de Florencia también contra los moros, este año de 1687, Cádiz, Alférez Bartolomé Núñez de Castro, 1687.

Relación verdadera y noticias generales venidas con el correo de Flandes en 1 de enero de 1684, Sevilla, Cristóbal López, 1684.

Relación verdadera, de las vitorias Que han tenido las Armas de Moscovia contra Turcos, Y vitoria obtenida por la Armada de Francia contra los Moros de Argel. Y otra vitoria que tuvieron las Galeras del señor Duque de Florencia, también contra Moros. Este año de 1687, Cádiz, Bartolomé Núñez de Castro, s.a.: ca. 1687.

Rodríguez Polo, Mario, «El duque de Lira a su paso por Polonia», Eslavística Complutense, 8, 2008, pp. 207-231. 
Román, Jerónimo, Tercera parte de las repúblicas del mundo, Salamanca, Juan Fernández, 1595.

Sagredo, Juan, Memorias históricas de los monarcas otomanos, Madrid, Juan García, 1684.

Schop Soler, Ana María, Un siglo de relaciones diplomáticas y comerciales entre España y Rusia 1733-1833, Madrid, Ministerio de Asuntos Exteriores, 1984.

Sherley, Anthony, Peso político de todo el mundo, BNE, ms. 999.

Smokti, Eugenia, «El mundo ruso en una comedia de Lope de Vega: la manipulación literaria» en I Coloquio Internacional "Los extranjeros en la España Moderna», ed. Mª. Begoña Villar y Pilar Pezzi, Málaga, Gráficas Digarza, 2003, II, pp. 721735.

Tamara, Francisco, El libro de las costumbres de todas las gentes del mundo y de las Indias, Amberes, Martín Nucio, 1556.

Torquemada, Antonio, Jardín de flores curiosas en que se tratan algunas materias de humanidad, filosofía, teología y geografía con otras cosas curiosas y apacibles, Amberes, Juan Cordeiro, 1575.

Villegas y Piñateli, Manuel de, Historia de Moscovia y vida de sus czares con una descripción de todo el imperio, su gobierno, religión, costumbres y genio de sus naturales, tomo primero, Madrid, Imprenta del convento de la merced, 1736.

Weiner, Jack, Mantillas en Moscovia. El teatro del Siglo de Oro español en la Rusia de los zares (1672-1917), Barcelona, PPU, 1988. 